\title{
AL-IJARAH AL-MUNTAHIYAH BI AL-TAMLIK (IMBT) \\ DALAM PERSPEKTIF HUKUM EKONOMI SYARIAH DAN APLIKASINYA SEBAGAI PRODUK PERBANKAN SYARIAH
}

\author{
Masrur Agus Alwi \\ Pascasarjana Universitas Islam Negeri SGD Bandung \\ E-mail: masrur17aa@gmail.com
}

\begin{abstract}
ABSTRAK
Al-Ijarah al- Muntahiyah Bi al-Tamlik -selanjutnya bisa disingkat IMBT- di dunia internasional dikenal juga dengan nama 'Hire-Purchase' atau 'Location Vente' adalah salah satu bentuk hybrid contract atau multi akad (al-Uqud al-Murakkabah) yang memadukan antara akad Ijarah dengan akad Ba'i atau Hibah. Jenis akad ini berbeda dengan akad Ijarah, karena memiliki karakteristik khusus yang mana dalam akad Ijarah hanya terjadi pemindahan hak guna manfat (Intiqol al-manfaah) sedangkan di IMBT terdapat opsi pemindahan kepemilikan (Intiqol al-Milkiyah) objek sewa melalui janji dari pemilik objek sewa. Implementasi hukum dari janji ini apakah mengikat atau tidak dalam perspektif ulama salaf/klasik berbeda-beda. Sebagian ada yang menegaskan bahwa janji harus dilaksanakan secara mutlak, sebagian mengatakan mengikat secara agama namun tidak secara yuridis, dan sebagian mengatakan mengikat secara agama dan yuridis dengan kondisi tertentu. Di Indonesia, akad ini sudah memiliki legalitas yuridis dalam standar operasional di Lembaga Keuangan Syariah dengan diterbitkannya beberapa peraturan perundang-undangan yang menjelaskan mekanisme dan prosuder baku akad IMBT. Sehingga oleh Bank-bank Syariah bisa menjadikan akad ini sebagai produk yang mereka tawarkan ke nasabah.
\end{abstract}

Kata kunci: Al-Ijarah al-Muntahiyah Bi al-Tamlik, Hybrid Contract, Produk Perbankan Syariah. 


\section{PENDAHULUAN}

Era Post-Industrial sangat korelatif dengan globalisasi dan liberalisasi di sektor ekonomi. ${ }^{1}$ Dua entitas perekonomian ini menurut teori Neo-Klasik bertujuan untuk menghilangkan kepincangan ekonomi dan mendorong terjadinya stabilitas ekonomi dunia. ${ }^{2}$ Namun, dalam perkembangannya, kedua hal ini acap kali menciptakan resiko krisis ekonomi dalam skala domestik maupun internasional yang dirasakan oleh masyarakat ekonomi dunia. Hal ini memberikan implikasi negatif dalam pranata ekonomi yang kompleks dan signifikan sehingga menuntut adanya inovasi-inovasi pemecah permasalahan bagi masyarakat dunia. ${ }^{3}$ Banyak negara berkembang bahkan negara maju sekalipun mengalami resesi ekonomi. Tingkat persaingan usaha dan bisnis internasional yang tidak sehat dan berimbang dalam skala makroekonomi memicu restrukturalisasi ekonomi dan reformasi birokrasi suatu negara, termasuk negara Indonesia.

Heterogenitas dinamika sosial dan ekonomi yang bermunculan di tengah masyarakat Indonesia lebih condong ke

1 "Liberalisasi ekonomi adalah reformasi ekonomi yang dilancarkan untuk menciptakan ekonomi berbasis pasar. Liberalisasi dapat diwujudkan dengan mengurangi regulasi pemerintah dan batasan-batasan lainnya terhadap kegiatan ekonomi. Selain itu, liberalisasi juga dapat diwujudkan lewat privatisasi badan usaha milik pemerintah, penurunan pajak untuk usaha, dan penghapusan batasan terhadap modal asing." Lihat: https://id.wikipedia.org/wiki/Liberalisasi_ekonomi. Diakses pada 8 Desember 2019, pukul 21:20.

2 Deliarnov, Ekonomi Politik, Jakarta: Erlangga, 2006, hlm. 205.

${ }^{3}$ Hetifah Sj. Sumarto, Inovasi, Partisipasi dan Good Governence, Jakarta: Yayasan Obor Indonesia, 2009, hlm. 7. arah negatif sebagai akibat dari problematika ekonomi global. Ditambah dengan data statistik pertumbuhan penduduk Indonesia yang berada dalam tren positif, meningkat dari tahun ke tahun menambah daftar masalah. Jika hal ini tidak diimbangi oleh pertumbuhan ekonomi nasional yang baik, maka eksistensi dari krisis ekonomi itu semakin terlihat nyata. Implikasinya bagi masyarakat adalah ketersediaan lapangan kerja akan berkurang, terbatas dan langka. Karena dipicu oleh tingkat persaingan usaha dari dalam dan luar negeri yang tinggi, angka pengangguran dan kemiskinan akan meningkat. Gap antara penghasilan dengan kebutuhan sehari-hari yang harus dipenuhi semakin hari semakin lebar, sehingga memaksa sebagian orang untuk berimprovisasi mencari jalan keluar demi pemenuhan kebutuhan ekonominya.

Mobilitas pertumbuhan industri yang tinggi dengan tingkat produktifitas yang cepat dalam menghasilkan produk barang dan jasa, hingga distribusi ke tengah masyarakat, membuat para pelaku industri melihat dengan mata kuda, tidak lagi menghiraukan norma, etika sosial dan agama (halal dan haram). Maka, dapat dipastikan beragam praktek muamalah atau transaksi bermunculan dengan beragam warna, corak dan pola yang hanya berorientasi pada profit atau keuntungan semata.

Sebagai negara dengan jumlah populasi muslim terbesar di dunia, banyak di antara masyarakat muslim Indonesia terjebak dalam problematika sosial ekonomi ini sehingga mencari kesempatan dan 
menempuh tata cara yang dalam asumsinya benar tanpa melihat landasan hukumnya -baik hukum agama maupun positif- terlebih dahulu. Akan tetapi, banyak juga dari mereka yang berharap banyak dengan keterlibatan Pemerintah yang proaktif dalam menyusun dan menerbitkan regulasi-regulasi yang memihak kepentingan mereka.

Dalam hal ini, Majelis Ulama Indonesia -walaupun bukan lembaga Pemerintah- melalui Dewan Syariah Nasional (DSN) MUI, membantu Pemerintah memenuhi ekspektasi dan aspirasi masyarakat dengan mengeluarkan fatwa-fatwa terkait praktik muamalah dalam perekonomian dan keuangan yang benar dan sesuai ajaran Islam (syariah). Di antara bentuk usaha tersebut adalah dikeluarkannya fatwa no. 27 tahun 2002 tentang akad Al-Ijarah al-Muntahiyah Bi AlTamlik atau disingkat IMBT ini. Dengan dukungan Pemerintah melalui penerbitan berbagai peraturan perundang-undangan pendukung fatwa ini, maka terciptalah kepastian hukum (legal certainty) dalam akad ini, sehingga masyarakat bisa dengan aman dan nyaman mengaplikasikannya dalam transaksi keuangan mereka, baik dalam ruang lingkup orang perorangan/individu atau lembaga keuangan berbasis syariah.

\section{PEMBAHASAN}

Akad Al-Ijarah Al-Muntahiyah Bi AlTamlik selanjutnya bisa disingkat IMBT ini esensinya terdiri dari dua suku kata, yakni al-Ijrah dan al-Tamlik. Dua suku kata yang masing-masing memiliki termino- logi dan hukum yang berbeda dalam yurisprudensi Islam. Dimana secara lex specialis, al-Ijarah bermakna hak guna manfaat/sewa (lease) dan al-Tamlik bermakna hak milik (ownership).

\section{Perkembangan IMBT}

Model akad ini merupakan pengembangan akad Ba'i al-Taqsith atau jual beli kredit dengan menjaga status hak milik (untuk penjual) hingga angsurannya selesai ditunaikan (Vent Atem Cement). ${ }^{4}$

Resiko kredit macet seringkali dihadapi oleh para penjual yang menjual barang dagangannya dengan skema jual beli kredit, sehingga mendorong mereka untuk bereksperimen dengan format baru yang bisa menjauhkan mereka dari kerugian, seperti kontrak jual beli yang dibungkus dengan kontrak penyewaan atau al-Ijarah. Posisi penjual dalam akad sewa ini berubah menjadi yang menyewakan (mu'jir) atau pihak pertama dan pembeli sebagai penyewa (musta'jir) atau pihak kedua dan dinamakan kontrak sewa beli. ${ }^{5}$

Transaksi ini pada awal mulanya terjadi pada tahun 1846 di Inggris dengan nama Hire-Purchase atau sewa-beli, yang mana seorang penjual alat-alat musik menyewakan alat musiknya yang disertai dengan opsi pemberian kepemilikan barang di akhir masa penyewaan. Kemudian akad atau kontrak seperti ini menyebar di daratan Eropa dan bertrans-

${ }^{4}$ Al-'Umrani, Abdulloh bin Muhammad, Al-'Uqud al-Maaliyah al-Murakkabah, Beirut: Dar Kunuz Isybiliya, 1428, hlm. 200.

${ }^{5}$ Abu al-Lail, Ibrahim Dassuqi, Al-Bai' Bi al-Taqshith wa al-Butu' al-l'timaniyah, Muscat: Mathabi' alNahdhah, 1990, hlm. 26-27. 
formasi dari transakasi antar personal ke transaksi level pabrik industri.

Pabrik yang pertama kali mengaplikasikannya adalah pabrik "Singer" sebuah pabrik provider mesin rajutan di Inggris. Pihak pabrik menyerahkan produk-produknya kepada para pekerjanya dengan skema akad Ijarah dengan jaminan mereka bisa memilikinya di akhir masa penyewaan jika telah melunasi sejumlah uang sewa yang disetor secara periodik atau kredit. Jika mereka mampu memenuhinya, maka barang tersebut otomatis menjadi milik mereka, karena uang sewa ini sudah terhitung sebagai harga dari objek sewa tersebut.

Akad pembiayaan (Leasing) muncul di Amerika Serikat pada tahun 1953 dan pada tahun 1962 di Perancis dengan nama Credit Bail atau jaminan kredit. Akad semacam ini terbilang baru dalam skema IMBT dikarenakan adanya keterlibatan pihak ketiga dalam kontrak. Fungsi pihak ketiga ini adalah sebagai penyedia dana untuk pembiayaan objek sewa.

Pada tahun 1975 Jenis akad pembiayaan ini berpindah ke negara-negara Islam melalui penetrasi Bank-bank Islam yang menjadikannya sebagai bagian dari model instrumen investasi mereka. Tercatat bank yang menerapkan akad ini pada waktu itu adalah Bank Islam Malaysia. Dalam perkembangannya dari tahun 1975 sampai tahun 1988 terdapat lebih dari 20 negara Islam telah memanfaatkan akad ini. ${ }^{6}$

${ }^{6}$ Ibid, hlm. 200.
Ada beberapa terminologi yang dipakai sebagai nomenklatur dalam akad sewa jenis ini, di antaranya: ${ }^{7}$

- Al-Bai' al-Ijari ( البيع الإجاري) atau sewa jual

- Al-Iijaar al-Saatir lil Bai' الإيجار الساتر للبيع) (atau jual beli yang dibungkus dengan akad sewa terlebih dahulu.

- Al-Iijaar alladzi Yanqalibu Bai'an ( الإيجار atau sewa yang berubah menjadi jual beli secara otomatis.

- Al-Iijaar al-Muqtarin Bi Wa'din Bil Bai' ( atau sewa yang disertai dengan janji jual beli pada awal kesepakatan.

- Al-Ijarah al-Tamwiliyah ( الإجارة التمويلية ) atau pembiayaan leasing dengan menggunakan jasa orang ketiga.

\section{Definisi IMBT}

Al-Ijarah ( الإجارة )

Secara etimologi, al-Ijarah ( الإجارة ) diambil dari kata الأجر yang memiliki dua makna, yaitu:

1. Al-Kiraa wa al-Ujrah ( الكراء والأجرة ) yang berarti sewa dan upah

2. Al-Jabr (الجبر ) yang berarti paksaan

Ibnu Faris dalam Mu'jam Maqayiis alLughah menjelaskan kedua makna ini bisa digabungkan dalam satu pengertian bahwa upah untuk seorang pekerja merupakan suatu hal yang dipaksakan sebagai kompensasi atas usaha atau pekerjaan yang dilakukannya. ${ }^{8}$

7 Al-'Umrani, Abdulloh bin Muhammad, op. cit. hlm. 198.

8 Ibnu Faris, Ahmad bin Faris Zakariya, Mu'jam Maqayis al-Lughah, Kairo: Dar Ibn Jauzi, 2001, jilid 1, hlm.62. dan Ibnu Manzhur, Muhammad bin Mukrim, 
Sedangkan Ibnu Manzhur mengatakan, "Al-Ajru berarti ganjaran/imbalan atas suatu pekerjaan, bentuk pluralnya adalah alUjuur. Sedangkan al-Ijarah diambil dari kata

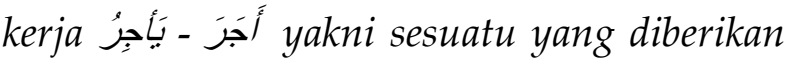
sebagai imbalan atas suatu pekerjaan."

Secara terminologi, al-Ijarah dalam definisi empat mazhab fikih memiliki pengertian yang hampir sama satu sama lain dan penulis menyimpulkan sebagai berikut,

Al-Ijarah adalah akad atas perpindahan hak guna (pemanfaatan) suatu objek tertentu ( (عبن atau objek dengan spesifikasi, identifikasi fisik ( موصوفة في الذمة diperbolehkan dalam rentang waktu tertentu dengan disertai imbalan (عوض ) tertentu yang telah disepakati bersama di awal akad. ${ }^{11}$

Dalam fatwa DSN-MUI No. 09/2000 tentang Pembiayaan Ijarah, Al-Ijarah dikategorikan dalam dua jenis, yakni:

1. Ijarah jasa/layanan dengan disertai upah atau fee ( أجرة ).

2. Ijarah hak guna (manfaat) dengan disertai pembiayaan sewa tanpa diikuti oleh pemindahan kepemilikan (عدم ( انتقال الملكية

\section{Al-Tamlik ( التمليك )}

Lisan al-Arab, Damaskus: Dar al-Ma'arif, 1998, jilid 4, hlm. 10.

${ }^{9}$ Ibnu Manzhur, op. cit. hlm. 12.

${ }^{10}$ Penyertaan kategori objek "al-Maushufah fi alDzimmah" ini terdalam dalam definisi Hanabilah. Lihat : https://www.alukah.net/sharia/0/67759/. Diakses pada 3 Desember 2019, pukul 10:13.

11 Lihat: Ibnu Abidin, Hasyiah Ibn Abidin, Beirut: Dar al-Ma'rifah, 1420, jilid 7, hlm. 9. Al-Qurofi dalam kitab al-Dzakhiroh 5/371. Al-Marghinani, Bidayatul Mubtadi, hlm. 186.
Secara etimologi, kata at-Tamlik berasal dari kata al-Milku ( الملك ) yaitu isim mashdar atau gerund dari derivasi ver-

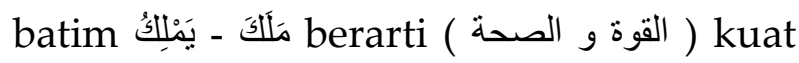
dan benar, seperti yang diterangkan oleh Ibnu Faris berikut, 12

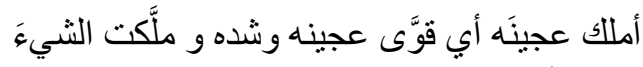

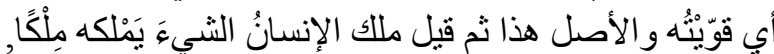

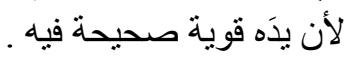

Adapun secara terminologi bisa disimpulkan, yaitu kepemilikan atas suatu objek disebabkan karena ada kuasa dan kemampuan atasnya.

\section{$I M B T$}

Al-Ijarah Al-Muntahiyah Bi Al-Tamlik (IMBT) merupakan akad yang muncul pada era modern ini dan salah satu bentuk pengembangan dari akad Ijarah yang telah ada sejak awal perkembangan Islam. IMBT termasuk salah satu bentuk produk hybrid contract atau multi akad ( dan dalam dekade terakhir ini banyak dikembangkan oleh lembagalembaga keuangan syariah baik nasional maupun internasional.

Berikut ini beberapa definisi IMBT dari beragam sumber, yaitu:

- "Kepemilikan atas hak guna (manfaat) objek tertentu dalam kurun waktu tertentu dengan disertai pembiayaan sewa (ujrah) tertentu yang terkadang lebih tinggi dari harga pasar/umum ( أجرة المثل). Pihak yang menyewakan (المؤجر memiliki hak kepemilikan atas objek sewa (العين العؤجرة) dan akan memberikan hak kepemilikannya tersebut kepada penyewa (الدستاجر) atas lan-

12 Ibnu Faris, op. cit. 5/351-352 dan al-Farahidi, Al'Ain, 5/380.

Jurnal Ilmu Akuntansi dan Bisnis Syariah 
dasan janji, di akhir masa penyewaan atau pertengahan jika penyeza mampu melunasi semua biaya sewa dengan tunai atau kredit melalui pembuatan akad baru yang terpisah, bisa dengan akad hibah atau akad jual beli dengan harga tertentu."13

- "Perjanjian antara dua pihak yang mana salah satu pihak menyewakan objek sewa tertentu kepada pihak lainnya dengan imbalan berupa biaya sewa yang dibayarkan oleh pihak penyewa secara kredit dalam tenor waktu tertentu dan pada akhir pembayaran terjadi pemindahan kepemilikan kepada penyeza dengan pembentukan akad baru."14

- "Perjanjian sewa-menyewa yang disertai opsi pemindahan hak milik atas benda yang disewa, kepada penyewa, setelah selesai masa sewa."15

- "Akad penyaluran dana untuk pemindahan hak guna (manfaat) atas suatu barang dalam waktu tertentu dengan pembayaran sewa (ujrah) antara perusahaan pembiayaan sebagai pemberi sewa (mu'ajjir) dengan penyewa (musta'jir) disertai opsi pemindahan hak milik atas barang tersebut kepada penyewa setelah selesai masa sewa."16

- "Dalam suatu benda antara mu'jir (yang menyewakan) dengan musta'jir (penyewa) diakhiri dengan pembelian ma'jur (objek sewa) oleh musta'jir (penyewa)."17

\footnotetext{
${ }^{13}$ Wahbah al-Zuhaili, Al-Mu'amalah al-maliyah alMu'ashiroh, Damaskus: Darul Fikri, 2002, hlm. 394.

${ }^{14}$ Al-Haafi Khalid, Al-ijarah al-Muntahiyah Bi alTamlik fi Dhau' al-Kitab wa as-Sunnah, hlm. 60

15 Lihat: Fatwa DSN-MUI No. 27 tahun 2002 tentang IMBT

${ }^{16}$ Lihat: Peraturan Badan Pengawas Pasar Modal dan Lembaga Keuangan (BAPEPAM dan LK) Nomor: PER.04/BL/2007 dalam bab Ketentuan Umum.

${ }^{17}$ Lihat: KHES bagian IX pasal 279.

Dari beberapa definisi di atas penulis menyimpulkan bahwa akad IMBT yang termasuk dalam al-'Uqud al-Murakkabah ${ }^{18}$ terdiri dari dua jenis akad yang berbeda dalam satu objek transaksi yang sama, dengan demikian memiliki hukum yang berbeda pula, yaitu akad Ijarah dan Bai' atau Hibah.

Pada awal perjanjian, akad yang digunakan kedua belah pihak adalah akad Ijarah sehingga terjadi pemindahan hak guna manfaat dari pihak pemberi sewa ( $\left.M u^{\prime} j i r / M u^{\prime} a j j i r\right)$ kepada pihak penyewa (Musta'jir) dengan disertai pemindahan hak milik ( انتقال الملكية ) dari Mu'jir kepada Mu'ajjir dengan landasan janji ${ }^{19}$ jika penyewa mampu melunasi semua biaya sewa di akhir masa sewa atau dipertengahan masa sewa dengan membayar tunai sisa sewa ${ }^{20}$. Janji $\left(W a^{\prime} d\right)$ hukumnya tidak mengikat -menurut fatwa DSN-MUI No. 27/2002- dan jika ingin dilaksanakan, maka bisa dilaksanakan di akhir tempo pembayaran biaya sewa atau masa akad Ijarah telah selesai dengan menggunakan akad baru, bisa dengan menggunakan akad Ba'i atau jual beli atau Hibah.

Dalam simpulan penulis, resultante dari definisi ini adalah akad IMBT ini hanya berlaku pada satu jenis Ijarah, yaitu ijarah dalam hal pemanfaatan barang atau

\footnotetext{
${ }^{18}$ Di referensi lainnya, disebut dengan terminologi al-'Uqud al-Maaliyah al-Murakkabah.

19 DSN-MUI menegaskan bahwa janji dalam akad IMBT ini tidak mulzim atau mengikat, walapun para ulama berselisih pendapat dalam hal ini. Penjelasan lengkap tentang hukum janji atau wa'ad bisa dilihat di hlm. 14.

${ }^{20}$ Lihat definisi IMBT oleh Wahbah Zuhaili hlm. 7.
} 
objek, bukan ijarah dalam pemanfaatan jasa atau layanan.

\section{Landasan Yuridis IMBT}

Secara lex generalis, landasan yuridis atau hukum akad IMBT merupakan duplikasi dari landasan yuridis yang dipakai dalam legitimasi akad ijarah, karena esensinya akad IMBT sendiri adalah bentuk pengembangan dari akad ijarah itu sendiri.

\section{Al-Quran}

\section{a) Surat Al-Baqarah ayat 233:}

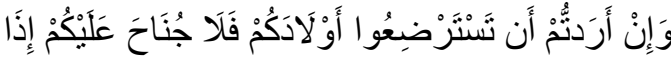

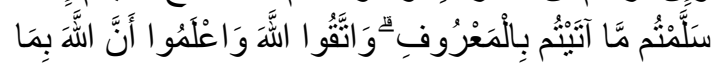

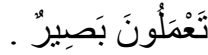

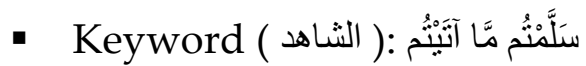

- Analisis konten (وجه الاستشهاد ): Allah ta'ala menghilangkan haraj dengan membolehkan seseorang untuk meminta atau menyewa wanita lain untuk menyusui bayinya jika itu meringkan beban istri yang telah ditalaknya dan dibarengi dengan pembayaran upah yang patut untuk jasa wanita tersebut. $^{21}$

b) Surat Al-Qashash ayat 26:

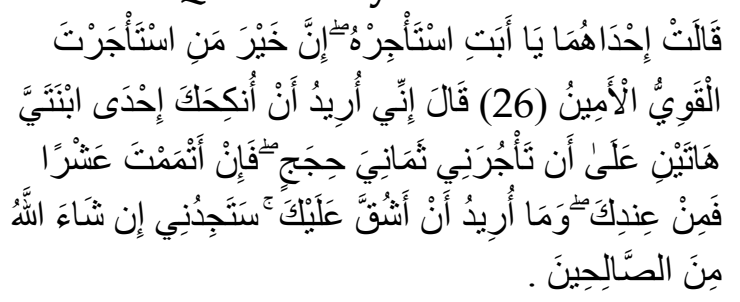

- Keyword ( اسنتَأْجِزْهُ : الثناهد

- Analisis konten (وجه الاستشهاد ): Seorang bapak tua dimana salah

21 Al-Thabari, Muhammad bin Jarir bin Yazid, Jami'ul Bayan fi Ta'wil Ayi al-Quran, Kairo: Muassasah al-Risalah, 2000, jilid 5, hlm. 71 satu anak gadisnya memintainya agar mau mempekerjakan Nabi Musa untuk menggembala kambing dengan target tertentu. Sebagai imbalan atas jasa/pelayanannya tersebut, maka si bapak akan menikahkan salah satu putrinya kepada Nabi Musa setelah selesai masa kontraknya.

c) Surat Al-Kahfi ayat 77:

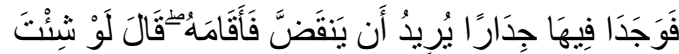

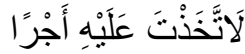

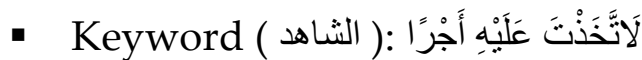

- Analisis konten ( وجه الاستشهاد ): Musa menyuruh kepada Nabi Khidir untuk mengambil upah dari pekerjaannya (jasa) yaitu membangun kembali tembok yang hampir roboh.

Kedua ayat di atas (b dan c) walaupun secara nash merupakan syariat orang terdahulu ( شرع من قبلنا ) dan para ulama pun berselisih tentang kehujjahannya, namun sebagian ulama di kalangan empat mazhab fikih menegaskan kehujjahannya, maka muncul kaidah, شرع من قبلنا شرع لنا "syariat orang terdahulu bisa dijadikan syariat bagi kita" dan dhabitnya adalah jika syariat diam akan hal tersebut ( سكت عنه ) tidak me-nasakh-nya dan Rasululloh pun tidak melarangnya. ${ }^{22}$

Al-Hadits

a) Dari Sa'ad bin Abi Waqqash berkata,

22 Lihat: Amir Syarifuddin, Ushul Fiqih, Jakarta: Kencana Prenada Media Group, 2008, hIm. 445-446. 


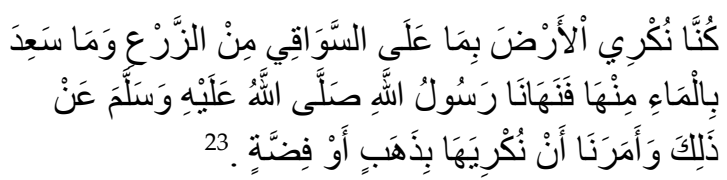

- Perawi hadits: Abu Daud

- No. hadits: 2943/3391 versi Baitul Afkar Ad-Dauliyah

- Derajat hadits: Hasan menurut Syekh Al-Albani

- Analisis konten: Hadits ini menunjukkan bahwa praktek penyewaan tanah diperbolehkan, namun terdapat permasalahan terkait pembayaran biaya sewa, apakah menggunakan uang (mablagh) atau harta benda lainnya atau dengan jasa. Para ulama berbeda pendapat, namun mayoritas ulama memperbolehkan dengan semua kategori di atas, kecuali Hanafiyah yang melarang menggunakan jasa sebagai iwadh karena masuk dalam kategori riba nasi'ah. ${ }^{24}$ Ibnu Rusyd menjelaskan dalam kitabnya Bidayatul Mujtahid bahwa semua benda yang bisa diperjualbelikan bisa menjadi uang sewa dalam ijarah. ${ }^{25}$

Menurut penulis, jika melihat tektual hadits di atas, para sahabat dulu mengambil upah sewa dari tanah yang disewakan dengan

23 Artinya: "Kami pernah menyewakan tanah dengan (bayaran) hasil tanaman yang tumbuh pada parit dan tempat yang teraliri air; maka Rasulullah melarang kami melakukan hal tersebut dan memerintahkan agar kami menyewakan tanah itu dengan emas atau perak (uang)."

${ }^{24}$ Al-Alifi, Muhammad bin Habr, Ta'rif al-ljarah fi al-Fiqh al-Islami. Lihat: https://www.alukah.net/sharia/0/125952/. Diakses pada 4 Desember 2019, pikul 18:16.

${ }^{25}$ (Bidayatul Mujtahid 2/220) mengunakan tanaman rambatan yang tumbuh disekitar aliran air dan hal ini dilarang secara sharih oleh Rasululloh SAW dan menyuruh para sahabat mengambil upah sewa dengan menggunakan emas atau perak (uang). ${ }^{26}$ Dan pelarangan pembayaran uang sewa ini korelasinya hanya dengan tipe ijarah objek barang tertentu bukan ijarah manfaat jasa/layanan.

b) Dari Abdullah bin Umar berkata, Nabi SAW bersabda,

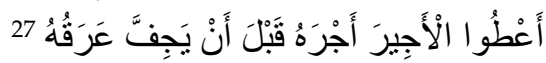

- Perawi hadits: Ibnu Majah

- No. hadits: 2434/2443 versi Maktabah al-Ma'arif Riyadh

- Derajat hadits: Shahih menurut Syekh Al-Albani

- Analisis konten: Hadits ini menegaskan bahwa jika seseorang mempekerjakan orang lain, maka ia diperintahkan oleh Syariat agar memberikan imbalan/upah kepadanya sebelum keringatnya mengering. Maksudnya adalah hal ini dalam konteks al-mubalaghah yaitu dengan mempercepat pembayaran dan jangan diundur-undur. ${ }^{28} \mathrm{Hal}$ senada juga disebutkan dalam hadits riwayat Abd Razzaq dari Abu Hurairah,

${ }^{26}$ Qal'ahji Muhammad Rawwas, Al-Mausu'ah alFiqhiyyah al-Muyassarah, Beirut: Dar an-Nafais: 2010, jilid 1, hlm. 48.

27 Artinya: "Berikanlah pekerja upahnya sebelum keringatnya mengering."

${ }^{28}$ Al-Mulla al-Qari, Ali bin Muhammad, Mirqhat alMafatiih Syarh Misykaat al-Mashabiih, Beirut: Darul Fikri, 2002, jilid 5, hlm. 1993. 


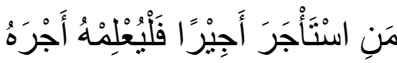

"Barangsiapa yang mempekerjakan seseorang, hendaklah ia memberitahu upahnya".

Sinkronisasi kedua hadits ini bisa mengarah pada implementasi asas konsensualisme dalam kontrak kerja, dimana harus ada transparansi dalam pemenuhan hak dan pelaksanaan kewajiban. Setelah kewajiban ditunaikan, maka pemenuhan hak pekerja berupa upah harus segera direalisasikan.

c) Dari Amr bin 'Auf al-Muzani, Rasululloh SAW bersabda,

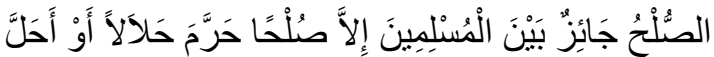

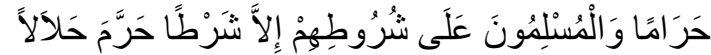

$$
\begin{aligned}
& \text { أَوْ أَحَلَّ حَرَامَا } 29
\end{aligned}
$$

- Perawi hadits: At-Tirmidzi

- No. hadits: 1272/1352 versi Maktabah al-Ma'arif Riyadh

- Derajat hadits: Hasan shahih menurut Abu Musa dan Al-Albani

- Analisis konten: Perjanjian pada esensinya diperbolehkan dalam Islam selama berada dalam koridor yang sesuai dengan tuntunan syariat. As-Shan'ani dalam Subulus Salam menjelaskan bahwa as-Sulhu dalam hadits ini bermakna heterogen dan tidak terbatas hanya dalam satu dimensi saja serta tidak

\footnotetext{
${ }^{29}$ Artinya: "Perjanjian dibolehkan di antara kaum muslimin kecuali perjanjian yang mengharamkan yang halal dan menghalalkan yang haram. Orang muslim terikat dengan syarat-syarat mereka kecuali syarat yang mengharamkan yang halal dan menghalalkan yang haram." Dalam fatwa No. 9 tahun 2000 tentang Pembiayaan ljarah, DSN-MUI menerjemahkan al-Sulh dengan perdamaian.
}

hanya melibatkan pihak sesama muslim saja, namun bisa pula perjanjian antara muslim dan kafir jika dipandang terdapat kemashlahatan di dalamnya. ${ }^{30}$ Dan dalam hadits ini ditekankan pula pelaksanaan dan pemenuhan janji-janji atau kesepakatan-kesepakatan bersama yang telah tertuang dalam klausaklausa perjanjian yang mengikat kedua belah pihak.

d) Dari Ibnu Mas'ud berkata,

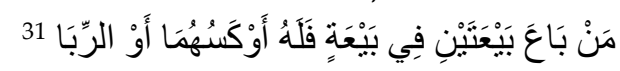

- Perawi hadits: Abu Daud

- No. hadits: 3002/3461 versi Baitul Afkar ad-Dauliyah

- Derajat hadits: Hasan menurut Syekh Al-Albani

- Analisis konten: IMBT merupakan salah satu jenis transaksi hybrid contract atau multi akad ( العقود المالية yaitu terjadinya 2 jenis akad atau lebih dalam satu transaksi. Istidlal menggunakan hadits ini untuk akad IMBT karena masuk dalam kriteria hadits di atas. Akan tetapi, penjelasan lebih lanjut tentang takyif shahih atau mekanisme yang sesuai syariah untuk akad IMBT akan dibahas di pembahasan tersendiri.

\section{Ketiga: Hukum Positif di Indonesia}

30 Al-Shan'ani, Muhammad bin Ismail bin Ahmad, Subul al-Salam, Beirut: Darul Hadits, 1999, jilid 2, hlm. 83.

${ }^{31}$ Artinya: "Siapa saja melakukan dua transaksi jual beli dalam satu akad jual beli, maka yang halal baginya adalah salah satunya atau dia sama dengan melakukan riba." 
Landasan IMBT dalam hukum perdata di Indonesia dapat ditemukan di beberapa peraturan perundang-undangan, yaitu:

a) UU No. 10 Tahun 1998 tentang Perubahan atas UU No. 07 Tahun 1992 tentang Perbankan pada pasal 1 nomor 12 yang berisi tentang pembiayaan perbankan dengan prinsip syariah $^{32}$ dan nomor 13 yang berisi tentang penjelasan prinsip syariah. ${ }^{33}$

b) UU No. 21 Tahun 2008 tentang Perbankan Syariah dalam pasal 1 angka 25, yang intinya menjelaskan bahwa pembiayaan adalah menyediakan dana atau tagihan yang dipersamakan dengan itu berupa transakasi sewamenyewa dalam bentuk ijarah atau sewa beli dalam bentuk ijarah muntahiya bi al-tamlik.

c) PBI No. 9/19/PBI/2007 tentang Pelaksanaan Prinsip Syari'ah dalam Kegiatan Penghimpunan Dana dan Penyaluran Dana serta Pelayanan Jasa Bank

\footnotetext{
32 Pasal 1 nomor 12, "Pembiayaan berdasarkan Prinsip Syariah adalah penyediaan uang atau tagihan yang dipersamakan dengan itu berdasarkan persetujuan atau kesepakatan antara bank dengan pihak lain yang mewajibkan pihak yang dibiayai untuk mengembalikan uang atau tagihan tersebut setelah jangka waktu tertentu dengan imbalan atau bagi hasil."

33 Pasal 1 nomor 13, "Prinsip Syariah adalah aturan perjanjian berdasarkan hukum Islam antara bank dengan pihak lain untuk menyimpan dana dan atau pembiayaan kegiatan usaha, atau kegiatan lainnya yang dinyatakan sesuai dengan syariah, antara lain pembiayaan berdasarkan prinsip bagi hasil (mudharabah), pembiayaan berdasarkan prinsip penyertaan modal (musharakah), prinsip jual beli barang dengan memperoleh keuntungan (murabahah), atau pembiayaan barang modal berdasarkan prinsip sewa murni tanpa pilihan (ijarah), atau dengan adanya pilihan pemindahan kepemilikan atas barang yang disewa dari pihak bank oleh pihak lain (ijarah wa iqtina)."
}

Syari'ah, sebagaimana yang diubah dalam PBI No. 10/16/PBI/2008, menyebutkan antara lain, Pemenuhan Prinsip Syari'ah sebagaimana yang dimaksud, dilakukan melalui kegiatan penyaluran dana berupa pembiayaan dengan menggunakan akad antara lain: Musyarakah, Mudharabah, Murabahah, Salam, Istisna', Ijarah IMBT dan Qard.

d) Surat Keputusan Ketua Bapepam dan LK Nomor: PER-04/BL/2007 tentang Akad-akad yang Digunakan dalam Kegiatan Perusahaan Berdasarkan Prinsip Syariah.

e) Fatwa DSN-MUI No. 27/MUI-
DSN/III/2002 tentang IMBT

\section{Perkara-perkara Fikih Terkait Akad IMBT}

\section{a. Janji atau Wa'ad ( الوعد )}

Janji dalam perspektif jumhur ulama dari kalangan ulama Syafi'iyyah, Hanabilah $^{34}$ dan sebagian Malikiyah adalah mulzim atau mengikat secara agama (diyanah) namun tidak secara hukum (qadha). ${ }^{35}$ Argumentasi mereka adalah pemenuhan janji itu merupakan bentuk ihsan atau berbuat baik dan tabarru' dari mu'jir kepada musta'jir. Dan kedua hal itu atas dasar sukarela dan tanpa paksaan. Dalil

${ }^{34}$ Ibnu Muflih, Ibrahim bin Muhammad, Al-Mubdi' fi Syarh al-Muqni', Damaskus: Al-Maktab al-Islami, 1394, jilid 9, hlm. 394.

35 Lihat: Al-Futuhat al-Rabbaniyah 'alal Adzkar aNawawiyah, 6/258 dan Penelitian Dr. Hasan al-Syadzili di majalah Majma' al-Fiqh al-Islami, pertemuan kelima di Kuwait. 
yang dipakai adalah surat al-Taubah ayat $91,{ }^{36}$

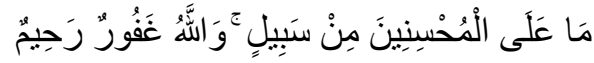

Artinya, "Tidak ada jalan sedikitpun untuk menyalahkan orang-orang yang berbuat baik. Dan Allah Maha Pengampun lagi Maha Penyayang."

Argumentasi ini dipakai oleh DSNMUI dalam fatwanya No. 27/2002 tentang IMBT dalam mengambil kebijakan dengan menetapkan hukum janji di akad IMBT ini tidak mulzim atau mengikat secara hukum. Ini menegaskan juga bahwa mu'jir jika berkeinginan akan melaksanakan janji pemindahan hak kepemilikan objek sewa kepada musta'jir, maka ia harus melakukan akad baru di akhir masa sewa selesai dengan akad Bai'/jual beli atau Hibah/pemberian. ${ }^{37}$

Namun, jika ditelaah lebih lanjut, hukum janji di fatwa ini kontradiktif dengan hukum janji dalam fatwa DSN-MUI No. 85 tahun 2012 tentang Janji (Wa'ad) dalam Transaksi Keuangan dan Bisnis Syariah, DSN-MUI mengatakan dengan jelas sekali di Ketentuan Hukum bahwa Janji bersifat mulzim atau mengikat secara hukum dan wajib dilaksanakan. ${ }^{38}$

36 Al-'Aani, Muhammad Ridho Abdul Jabbar, Quwwatul wa'd al-Mulzimah fi al-Syari'ah wa alQonun, Majalah Majma' al-Fiqh al-Islami, edisi 5, jilid 5, hlm. 556.

Lihat: https://al-maktaba.org/book/8356/9145\#p1

37 Ketentuan IMBT Nomor 2, "Janji pemindahan kepemilikan yang disepakati di awal akad ljarah adalah wa'd (لوعد), yang hukumnya tidak mengikat. Apabila janji itu ingin dilaksanakan, maka harus ada akad pemindahan kepemilikan yang dilakukan setelah masa ljarah selesai."

${ }^{38}$ Ketentuan Hukum: "Janji (wa'd) dalam transaksi keuangan dan bisnis syariah adalah mulzim dan wajib
Sedangkan menurut Hanafiyah, janji mengikat secara hukum jika dikaitkan dengan sesuatu, misalkan perkataan mu'jir kepada musta'jir, "jika kamu memenuhi semua pembayaran kredit, maka saya akan menjual barang sewaan ini kepadamu.". ${ }^{39}$ Pendapat yang terkenal (masyhur) dalam mazhab Malikiyah adalah janji mengikat secara hukum jika ada sebab dan sebab itu dinyatakan jelas dalam janji. Wahbah Zuhaili mengemukakan argumentasi penguat terkait pendapat Malikiyah ini, "Janji itu mengikat secara hukum jika yang dijanjikan tersebut termasuk dalam kewajiban materiil/finansial ( التزام مالي ( ). Dengan demikian, seorang penyewa harus komitmen dan berkewajiban atas pembayaran uang sewa yang bisa jadi lebih mahal dari harga sewa pasar, maka janji disini mengikat. ${ }^{40}$ Kedua pendapat ini kohesif dengan kaidah fikih:\

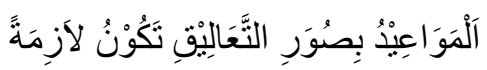

"Janji dengan bentuk bersyarat bersifat mengikat." 41

Pandangan Malikiyah ini juga digunakan oleh Majma' al-Fikh al-Islami dalam keputusannya No. 40-41 di pertemuan ke-5 di Kuwait secara garis besar menjabarkan bahwa janji yang berasal dari pihak pertama dan kedua

dipenuhi (ditunaikan) oleh wa'id dengan mengikuti ketentuan-ketentuan yang terdapat dalam Fatwa ini."

39 Lihat: Al-Hamawi, Ahmad bin Muhammad, Ghamz al- 'Uyun Syarh al-Asybah wa al-Nazha-ir, Beirut: Dar al-Fikri, 1970, jilid 3, hlm. 237.

${ }^{40}$ Wahbah al-Zuhaili, op. cit., hlm. 402.

41 'Athiyah Adlan 'Athiyah Ramdhan, Mausu'ah alQawa'id al-Fiqhiyyah, Iskandariyah: Dar al-Iman, 2007, hlm. 101. 
bersifat mengikat satu sama lain secara agama kecuali ada udzur syar'i yang menghalangi dan mengikat juga secara hukum jika dikaitkan dengan suatu sebab. Konsekuensinya adalah harus terciptanya pemenuhan atas janji tersebut dengan cara melaksanakannya atau mengganti kerugian materiil yang ditimbulkan oleh pembatalan atau pelanggaran janji tersebut. ${ }^{42}$

Beberapa ulama salaf seperti Ibn Syubrumah, Hasan al-Bishri, Samrah bin Jundub, al-Qadhi Sa'id bin Asywa' al-Kufi, dan Ibnu Rahawaih berpendapat bahwa janji hukumnya mengikat secara mutlak. Pendapat ini juga dipilih oleh Syeikhul Islam Ibnu Taimiyah. ${ }^{43}$ Pendapat terakhir ini dijadikan landasan dalam fatwa Muktamar Bank Islam pertama di Dubai tahun $1399 \mathrm{H}$ dan kedua pada tahun $1403 \mathrm{H}$.

\section{b. Dua Akad dalam Satu Transaksi}

Dalam hadits riwayat Abu Daud, an-Nasa'i dan at-Tirmidzi dari Abdullah bin 'Amr, Rasululloh SAW bersabda,

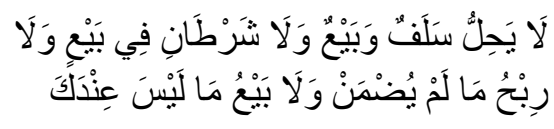

Artinya, "Tidak halal menggabungkan utang dengan jual beli, tidak pula dua syarat dalam jual beli, tidak pula keuntungan tanpa ada pengorbanan, dan

\footnotetext{
${ }^{42}$ Wahbah al-Zuhaili, loc. cit.

${ }^{43}$ Lihat: Al-Ba'li, Ali bin Muhammad, Al-lkhtiyarat al-Fiqhiyyah Min Fatawa Syeikh al-Islam Ibn Taimiyah, Riyadh: Muassasah al-Sa'idiyah, 1990, hlm. 331.
}

tidak pula menjual barang yang tidak kamu miliki." (HR. Ahmad 6671, Abu Daud 3506, Turmudzi 1279 dan dihasankan Syuaib al-Arnauth).

Hadits tentang pelarangan dua akad dalam satu transaksi4 ${ }^{44}$ di atas tidak ada relevan jika digunakan untuk delegitimasi akad IMBT, karena IMBT pada dasarnya terstruktur dari dua akad berbeda yang berdiri sendiri, terpisah oleh waktu yang dikaitkan

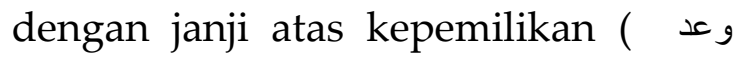
(بالتمليك ). Janji itu sendiri bukanlah sebuah akad dan proses perpindahan kepemilikan atas objek ijarah dari mu'jir ke musta'jir menggunakan akad tersendiri yang terpisah dari akad Ijarah, bisa dengan akad jual beli atau hibah.

Hal ini juga dituangkan oleh Majlis Majma' al-Fikh al-Islami dalam keputusannya No. 110 tentang IMBT dan Sukuk ijarah di pertemuan yang ke-10 di Riyadh, Arab Saudi pada tanggal 23-28 September 2000. Dijelaskan di dalam Dhabith al-Jawaz (batasan pembolehan) bahwa IMBT harus menggunakan dua akad yang terpisah satu sama lain oleh waktu, dengan ketentuan pelaksanaan akad Ba'i terjadi setelah akad Ijarah selesai disertai oleh janji kepemilikan di akhir masa sewa. ${ }^{45}$ Hal senada juga dituangkan oleh DSN-MUI di dalam fatwanya No. 27

\footnotetext{
44 Riwayat Ahmad dari Ibnu Mas'ud,

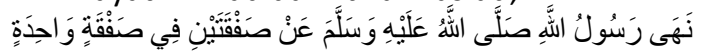
Artinya, "Rasulullah melarang dua bentuk akad sekaligus dalam satu obyek."

45 Lihat: Majalah Majma' al-Fiqh al-Islami, Pertemuan ke-12, jilid 1. HIm. 697-699.
} 
tahun 2002 di dalam ketentuan tentang IMBT pada nomor $1 .{ }^{46}$

\section{c. Jaminan dan Pemeliharaan Objek Ijarah}

Jaminan dan Pemeliharaan objek sewa menjadi tanggung jawab penyewa sebagai pemilik barang tersebut dan bisa dilakukan sendiri oleh dirinya langsung atau menunjuk orang lain yang mewakilkan.

Adapun menurut keputusan Majma' Fikih Islami No. 110 tahun 2000 tentang IMBT dan fatwa DSN-MUI No. 9 tahun 2000 tentang Pembiayaan Ijarah, dijelaskan beberapa poin berikut:

1. Mu'jir berkewajiban menanggung semua biaya pemeliharaan objek sewa tersebut.

2. Mu'jir harus menjamin barang yang disewakan jika ditemukan ada cacatnya. Dan jika menggunakan at-Ta'min atau asuransi, maka asuransi yang digunakan adalah at-Ta'min at-Ta'awuni bukan at-Tijari.

3. Musta'jir harus merawat keutuhan objek sewa selama pemakaian yang sesuai dengan kesepakatan dalam akad.

4. Musta'jir menanggung biaya pemeliharaan objek yang sifatnya ringan atau non-materiil.

46 Ketentuan IMBT Nomor 1, "Pihak yang melakukan al-ljarah al-Muntahiah bi al-Tamlik harus melaksanakan akad ljarah terlebih dahulu. Akad pemindahan kepemilikan, baik dengan jual beli atau pemberian, hanya dapat dilakukan setelah masa ljarah selesai."
5. Musta'jir tidak bertanggung jawab atas kerusakan yang tidak disebabkan oleh penggunaan yang diperbolehkan atau kelalaian.

Uniknya, Wahbah Zuhaili mengemukakan klausa tentang pemeliharaan objek sewa, "Jika dilakukan oleh penyewa dengan seizin ataupun tanpa seizin pemilik, maka diperbolehkan selama tidak menimbulkan kerusakan lebih parah dan itu dianggap sebagai bentuk kesukarelaan." 47

\section{Skema IMBT dan Analisis Hukumnya}

Jenis akad ini memiliki beragam format, ada yang diperbolehkan karena sesuai dengan syariat namun aja juga yang tidak sesuai dengan syariat, maka operasionalnya dilarang. Berikut akan ditampilkan skema akad IMBT yang dikategorikan dalam dua kategori sesuai status hukumnya, yaitu: ${ }^{48}$

\section{* Skema IMBT yang Diperbolehkan}

Skema pertama:

Akad Ijarah yang mana musta'jir bisa memanfaatkan objek sewa dengan feedback atau imbalan bagi mu'jir berupa uang sewa selama kurun waktu tertentu dengan disertai akad Hibah atau pemberian objek sewa yang dikaitkan dengan pelunasan semua pembiayaan sewa. Akad hibah ini dilaksanakan setelah akad Ijarah selesai.

\section{Skema kedua:}

${ }^{47}$ Ibid, hlm. 403.

48 Lihat: Keputusan Majelis Majma' al-Figh alIslami Nomor 110 (12/4) tahun 2000 tentang IMBT dan Sukuk ljarah di pertemuan ke-12 di Riyadh, Arab Saudi. 
Akad ljarah yang mana mu'jir memberikan opsi memilih bagi musta'jir setelah melunasi semua pembiayaan sewa dalam kurun waktu yang telah disepakati untuk:

- Membeli objek sewa dengan harga sesuai kesepakatan

- Menghentikan akad Ijarah dan mengembalikan objek sewa ke mu'jir

- Memperpanjang tempo sewa

\section{Skema ketiga:}

Akad Ijarah yang mana musta'jir bisa memanfaatkan objek sewa dengan feedback atau imbalan bagi mu'jir berupa uang sewa selama kurun waktu tertentu dengan disertai janji untuk menjual ( وعد بييع ) objek sewa yang dengan syarat pelunasan semua pembiayaan sewa dengan harga jual yang disepakati bersama. Akad jual beli dilaksanakan setelah akad Ijarah selesai.

\section{Skema keempat:}

Akad Ijarah yang mana musta'jir bisa memanfaatkan objek sewa dengan feedback atau imbalan bagi mu'jir berupa uang sewa selama kurun waktu tertentu dan mu'jir menawarkan hak memilih bagi Musta'jir untuk memiliki objek sewa kapan pun Musta'jir bersedia sampai jual beli terlaksana pada waktunya dengan akad jual beli baru dan memakai harga pasar atau kesepakatan bersama.

\section{Skema IMBT yang Dilarang}

\section{Skema pertama:}

Akad Ijarah yang berakhir dengan perpindahan kepemilikan objek sewa sebagai imbalan atas biaya sewa yang dikeluarkan atau dibayarkan oleh musta'jir kepada mu'jir pada kurun waktu tertentu tanpa pembentukan akad baru. Disini terjadi transformasi akad dari ljarah ke Ba'i secara otomatis.

\section{Skema kedua:}

Seorang pembeli -orang atau lembaga- membeli barang dari seorang penjual kemudian si pembeli tersebut menyewakannya langsung kepada penjual tersebut sebelum harga pembelian diserahterimakan dan menjanjikan barang tersebut dijual kepadanya (penjual pertama). Jenis ini dilarang karena menyerupai Bai' al-'Inah dan musta'jir disini adalah penjual itu sendiri.

\section{Aplikasi IMBT di Perbankan Syariah}

Dalam perbankan syariah, aplikasi produk Ijarah (Operational Lease) dan IMBT (Financial Lease with Purchase Option), pihak Bank berfungsi sebagai investor/penyedia dana dan juga pemberi janji ( الواعد ( ).49 Akad IMBT seperti yang telah dijelaskan sebelumnya adalah produk pengembangan dari akad Ijarah dan diklasifikasikan dalam jenis hybrid contract atau multi akad ( العقود المركبة ). Bank Syariah dalam mengaplikasikan IMBT sebagai produk mereka dalam pembiayaan jangka menengah (Intermediate Term) dan jangka panjang (Long Term), biasanya diperuntukkan untuk:

${ }^{49}$ Andri Soemitra, Bank dan Lembaga Keuangan Syariah, Jakarta: Kencana, 2014, hlm. 85. 
1. Pembiayaan investasi; dalam hal ini bank menyalurkan pembiayaan untuk pengadaan barang-barang modal produktif seperti mesin. Jadi, pihak bank tidak semata-mata membeli barang ini untuk di dimiliki dan dijual, akan tetapi lebih kepada investasi ( الإستثمار).

2. Pembiayaan konsumer; seperti pembelian rumah, mobil dll. ${ }^{50}$

Standar operasional Bank-bank Syariah dalam mengoperasikan produk-produk mereka pada dasarnya tetap harus mengacu kepada standar baku yang diregulasikan dalam peraturan perundangundangan dan fatwa DSN-MUI. Terkait ketentuan dan standar operasional produk akad Ijarah dan IMBT bisa dilihat di fatwa DSN-MUI No. 27 tahun 2002 dan untuk lebih detail dan jelas bisa merujuk ke Surat Edaran Bank Indonesia No. 10/14/DPbS tertanggal 17 Maret 2008 sebagai penjelasan atas Peraturan Bank Indonesia (PBI) No. 9/19/PBI/2007 perihal Pelaksanaan Prinsip Syariah dalam Kegiatan Penghimpunan Dana dan Penyaluran Dana serta Pelayanan Jasa Bank Syariah. ${ }^{51}$

Dalam realisasinya, pihak Bank dapat melakukan leasing ( التمويل), baik dalam bentuk operating lease atau akad Ijarah murni maupun financial lease atau akad IMBT. Akan tetapi, pada umumnya,

\footnotetext{
50 Imam Mustofa, Fikih Muamalah Kontemporer, Jakarta: Raja Grafindo, 2016, hlm. 123.

${ }^{51}$ Lihat: Surat Edaran Bank Indonesia tertanggal 17 Maret 2008 No. 10/14/DPbS dalam Pokok Ketentuan III. 6 tentang akad ljarah, terdiri dari 2 poin: poin 1 terdiri dari 12 ketentuan dan poin 2 terdiri dari 3 ketentuan. Sedangkan di Pokok Ketentuan III.7 tentang akad IMBT, terdiri dari 5 ketentuan.
}

bank-bank tersebut lebih banyak menggunakan akad IMBT disebabkan karena lebih sederhana dari sisi pembukuan. Selain itu, bank pun tidak direpotkan untuk mengurus pemeliharaan aset, baik pada aset leasing maupun sesudahnya. ${ }^{52} \mathrm{Hal}$ ini disebabkan setelah masa akad Ijarah selesai dan dilanjutkan dengan proses pemindahan hak milik dengan akad Bai' atau Hibah. Skim ini

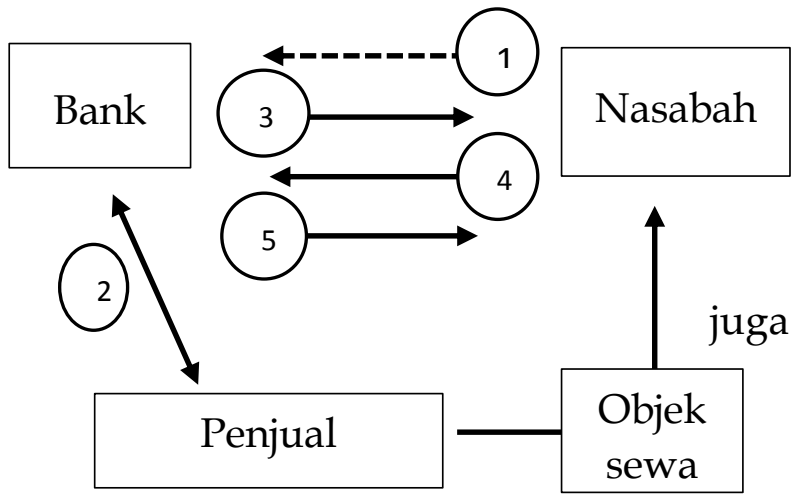

menarik bagi pihak bank syariah karena selama nilai sewa objek sewa ( الأعيان المؤجرة ) belum selesai ditunaikan oleh nasabah, maka objek sewa masih dalam kepemilikan bank dan bukan nasabah.

Terkait perihal penyewaan ini, Ibnu Quddamah dalam kitabnya al-Mughni men-tarjih pendapat yang memperbolehkan transaksi ini jika objek sudah dimiliki. Ibnu Quddamah berkata, 53

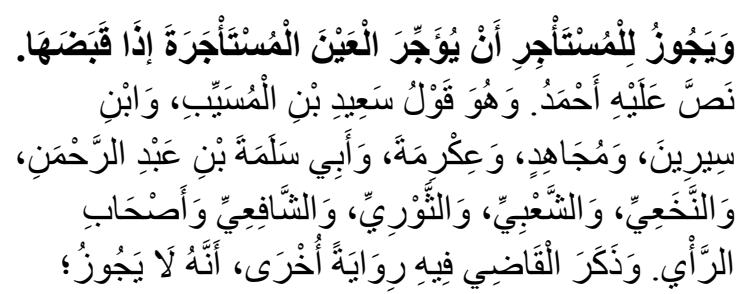

52 Muhammad Syafi'i Antonio, Bank Syariah dari Teori ke Praktik, Jakarta: Gema Insani Press, 2007, hlm. 118.

53 Ibnu Quddamah, Ahmad bin Muhammad, AlMughni, Kairo: Maktabah al-Qahiroh, 1968, jilid 5, hlm. 354.

Jurnal Ilmu Akuntansi dan Bisnis Syariah

105 


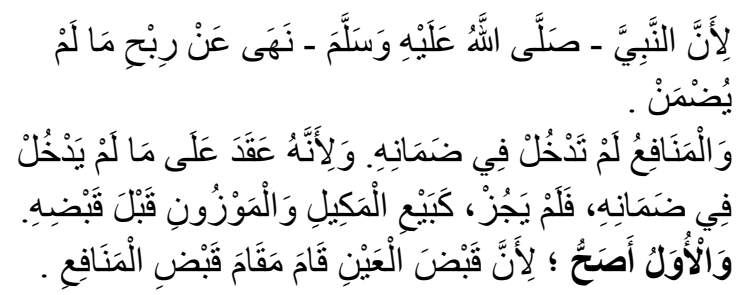

1. Bank dan Nasabah melakukan akad Ijarah lengkap dengan keterangan jumlah biaya sewa, jangka waktu, biaya perawatan dan klausula-klausula pelengkap lainnya. Tahap ini disertai juga dengan janji (و مد (5) dari Bank atas pemindahan hak kepemilikan objek sewa ( العين المؤجرة ) di akhir masa sewa kepada Nasabah jika dia mampu memenuhi kewajibannya. Dan selanjutnya, barang diserahkan ke Nasabah untuk dimanfaatkan.

2. Nasabah berkomitmen menyerahkan sejumlah biaya atau uang sewa secara kredit/periodik kepada Bank sesuai dengan kesepakatan di awal akad.

3. Di akhir masa sewa objek, Bank berhak melakukan akad baru (sesuai dengan fatwa DSN-MUI, pemilik objek sewa boleh menawarkan opsi) untuk memindahkan kepemilikan objek sewa ke Nasabah dengan akad Ba'i atau Hibah dengan beberapa kesepakatan terkait harga jual misalnya.

Alternatif pemindahan kepemilikan objek sewa: ${ }^{5}$

- Akad Bai' atau jual beli; akad ini dilakukan oleh Bank (mu'jir) jika melihat kemampuan finansial na-

54 Dalam fatwa DSN-MUI No. 27 tahun 2002 tentang IMBT tidak mengikat.

${ }^{55}$ Rachmadi Usman, Produk dan Akad Perbankan Syariah di Indonesia, Bandung: Citra Aditya Bakti, 2009, hlm. 242. sabah (musta'jir) untuk membayar biaya sewa relatif kecil. Dikarenakan biaya sewa yang diserahkan nasabah relatif kecil, akumulasi nilai sewa yang sudah diserahkan hingga akhir masa sewa tidak bisa memenuhi harga beli untuk menutupi kekurangan tersebut, bila nasabah ingin memiliki barang tersebut, ia harus membeli barang itu di akhir masa sewa dengan harga yang disepakati. Jika tidak, maka Bank bisa mengambil lagi objek sewa.

- Akad hibah; akad ini dipilih oleh Bank (mu'jir) bila melihat kemampuan finansial nasabah (musta'jir) untuk melunasi biaya sewa relatif lebih besar. dikarenakan biaya sewa yang ditunaikan relatif besar, akumulasi sewa di akhir masa sewa telah mencukupi untuk menutupi harga beli objek sewa dan margin keuntungan yang ditetapkan oleh Bank. Maka, Bank bisa menghibahkan/memberikan objek sewa tersebut di akhir masa sewa kepada nasabah (musta'jir).

\section{SIMPULAN}

Akad Al-ijarah al-Muntahiyah Bi alTamlik (IMBT) merupakan salah satu hybrid contract yang muncul pada abad ke-20 di daratan Eropa dan menjalar ke Asia. Perlu regulasi khusus dalam standar operasional akad ini di dalam masyarakat umum ataupun dalam lembaga-lembaga keuangan syariah. 
Akad IMBT adalah akad turunan atau perkembangan dari akad Ijarah, namun memiliki karakteristik berbeda dengan akad Ijarah pada umumnya. Di dalam akad IMBT terdapat opsi pemindahan kepemilikan atas objek sewa (الأعيان ) kepada penyewa atau musta'jir di akhir masa sewa atau setelah akad Ijarah selesai, dengan diikat atau disertai oleh janji atau wa'ad (وعد) dari pihak pemberi sewa atau Mu'jir yang sifatnya tidak mengikat. Akad pemindahan kepemilikan ini dilaksanakan dengan salah satu akad dari dua akad, yaitu dengan akad Bai' atau Hibah.

Di Indonesia sendiri, IMBT telah memiliki kelengkapan administrasi dalam legal standing dan legal formal operasionalnya di dalam Lembaga Keuangan Syariah seperti Perbankan Syariah. Regulasi-regulasi dari fatwa-fatwa DSN-MUI sebagai guidence muamalah syariah di Indonesia telah menerbitkan fatwa No. 27 tahun 2002 tentang akad ini. Bank Indonesia pun telah mengeluarkan beberapa peraturan dan surat edaran yang berisi penjelasan secara detail akan prosedur dan standar pelaksanaan pembiayaan dengan akad ini oleh bank. Sebelumnya telah terbit pula banyak peraturan perundang-undangan terkait masalah akad IMBT ini seperti UU No. 21 tahun 2008 tentang Perbankan Syariah dan sebelumnya UU No. 10 Tahun 1998 tentang Perubahan atas UU No. 07 Tahun 1992 tentang Perbankan.

Dengan penerbitan landasan yuridis dalam hukum positif di Indonesia di atas, diharapkan menciptakan kepastian hu- kum bagi masyarakat, sehingga mereka merasa aman dan nyaman dalam bertransaksi dengan menggunakan layanan akad IMBT ini. Dengan adanya kepastian hukum, keadilan hukum insya Allah bisa terwujud. 


\section{DAFTAR PUSTAKA}

Abu al-Lail, Ibrahim Dassuqi, 1990. Al-Bai' Bi al-Taqshith wa al-Buyu' al-I'timaniyah, Muscat: Mathabi' al-Nahdhah.

Al-'Umrani, Abdulloh bin Muhammad, 1428. Al-'Uqud al-Maaliyah al-Murakkabah, Beirut: Dar Kunuz Isybiliya.

Al-Ba'li, Ali bin Muhammad, 1991. Al-Ikhtiyarat al-Fiqhiyyah Min Fatawa Syeikh al-Islam Ibn Taimiyah, Riyadh: Muassasah al-Sa'idiyah.

Al-Haafi Khalid, 1410. Al-ijarah al-Muntahiyah Bi al-Tamlik fi Dhau' al-Kitab wa as-Sunnah, Beirut: Dar al-Fikr.

Al-Hamawi, Ahmad bin Muhammad, 1970. Ghamz al- 'Uyun Syarh al-Asybah wa alNazha-ir, Beirut: Dar al-Fikri.

Al-Mulla al-Qari, Ali bin Muhammad, 1993. Mirqhat al-Mafatiih Syarh Misykaat alMashabiih, Beirut: Darul al-Fikr.

Al-Qurofi, Ahmad bin Idris, 1406. Al-Dzakhiroh, Beirut: Dar al-Kitab al-Arabi.

Al-Qurthubi, Muhammad bin Rusyd, 1416. Bidayatul Mujtahid wa Nihyatul Muqtashid. Beirut: Dar Ibn Hazm.

Al-Shan'ani, Muhammad bin Ismail, 1999. Subul al-Salam Syarh Bulug al-Maram, Beirut: Darul Hadits.

Al-Siddiq, Muhammad Al-'Allaan, 1398. Futuhat al-Rabbaniyah 'alal Adzkar a-Nawawiyah, Beirut: Dar Al-Fikr.

Al-Thabari, Muhammad bin Jarir bin Yazid, 2000. Jami' al-Bayan fi Ta'wil Aayi al-Quran, Kairo: Muassasah al-Risalah.

Al-Zarqa, Ahmad Ibnu Muhammad, 1989. Syarh al-Qawa'id al-Fiqhiyyah, Damaskus: Dar al-Qalam.

Amir Syarifuddin, 2008. Ushul Fiqih, Jakarta: Kencana Prenada Media Group.

Andri Soemitra, 2014. Bank dan Lembaga Keuangan Syariah, Jakarta: Kencana Prenada Media Group.

Athiyah Adlan 'Athiyah Ramdhan, 2007. Mausu'ah al-Qawa'id al-Fiqhiyyah, Iskandariyah: Dar al-Iman.

Deliarnov, 2006. Ekonomi Politik, Jakarta: Erlangga.

Hetifah Sj. Sumarto, 2009. Inovasi, Partisipasi dan Good Governence, Jakarta: Yayasan Obor Indonesia.

Ibnu Abidin, Muhammad bin Abidin, 1420. Hasyiah Ibn Abidin, Beirut: Dar al-Ma'rifah.

Ibnu Faris, Ahmad bin Faris Zakariya, 2001. Mu'jam Maqayis al-Lughah, Kairo: Dar Ibn Jauzi.

Ibnu Manzhur, Muhammad bin Mukrim, 1998. Lisan al-Arab, Damaskus: Dar al-Ma'arif. 
Ibnu Muflih, Ibrahim bin Muhammad, 1394. Al-Mubdi' fi Syarh al-Muqni', Damaskus: Al-Maktab al-islami.

Ibnu Quddamah, Ahmad bin Muhammad, 1968. Al-Mughni, Kairo: Maktabah alQahiroh.

Imam Mustofa, 2016. Fikih Muamalah Kontemporer, Jakarta: Raja Grafindo.

Mardani, 2012. Fiqih Ekonomi Syariah Fikih Muamalah, Jakarta: Kencana Prenada Media Group.

Muhammad Syafi'i Antonio, 2007. Bank Syariah dari Teori ke Praktik, Jakarta: Gema Insani Press.

Qal'ahji Muhammad Rawwas, 2010. Al-Mausu'ah al-Fighiyyah al-Muyassarah, Beirut: Dar an-Nafais.

Rachmadi Usman, 2009. Produk dan Akad Perbankan Syariah di Indonesia, Bandung: Citra Aditya Bakti.

Wahbah al-Zuhaili, 2002. Al-Mu'amalah al-maliyah al-Mu'ashiroh, Damaskus: Darul Fikri.

\section{PERATURAN PERUNDANG-UNDANGAN}

UU No. 10 Tahun 1998 tentang Perubahan atas UU No. 07 Tahun 1992 tentang Perbankan

UU No. 21 Tahun 2008 tentang Perbankan Syariah

Fatwa DSN-MUI No. 9 Tahun 2000 tentang Pembiayaan Ijarah

Fatwa DSN-MUI No. 27 Tahun 2002 tentang IMBT

Fatwa DSN-MUI No. 85 Tahun 2012 tentang Janji dalam Transaksi Keuangan dan Bisnis Syariah

Keputusan Majelis Majma' al-Fiqh al-Islami Nomor 110 (12/4) tahun 2000 tentang IMBT dan Sukuk Ijarah

Peraturan Bank Indonesia No. 9/19/PBI/2007 tentang Pelaksanaan Prinsip Syari'ah dalam Kegiatan Penghimpunan Dana dan Penyaluran Dana serta Pelayanan Jasa Bank Syari'ah

Peraturan Badan Pengawas Pasar Modal dan Lembaga Keuangan (BAPEPAM dan LK) Nomor: 04/BL/2007

Surat Edaran Bank Indonesia tertanggal 17 Maret 2008 No. 10/14/DPbS

Kompilasi Hukum Ekonomi Syariah

WEBSITE:

https://www.alukah.net/sharia/0/67759

https://www.alukah.net/sharia/0/125952 
masrur agus alwi 